\title{
Kepala Keluarga dalam Islam (Telaah QS. Al-Nisa: 34)
}

\author{
Ahmad Afifuddin Al Amin \\ UIN Syarif Hidayatullah Jakarta \\ elahmadsyafii@gmail.com
}

\begin{abstract}
This article discusses the head of family in Islam by examining surah al-Nisa: 34 . This paper is a qualitative study using the Charles Sanders Peirce semiotic approach. This research is study literature. The sources in this study are kitab, books and journal articles that are relevant to the theme. Interpretation of QS. An-Nisa (4): 34 by taking some references to the views of the previous ulama, it can be concluded that men are the head of the "leader" family in a family setting.
\end{abstract}

Kata Kunci: Islam, Qur'an, Semiotic

\section{Pendahuluan}

Al-Qur`an adalah hujjah bagi umat manusia, dan hukumnya merupakan undangundang yang wajib dipatuhi. Di dalam al-Qur`an, ayat-ayat hukum yang mengatur mengenai hukum keluarga terdapat sebanyak 70 ayat, hal ini mengindikasikan bahwa institusi keluarga merupakan hal yang sangat urgen bdalam kehidupan manusia. Di samping itu, institusi keluarga merupakan lembaga terkecil dari masyarakat, baik lakilaki ataupun perempuan merupakan entitas penting dalam keluarga, sehingga pembicaraan keluarga tidak akan terlepas dari unsur-unsur pembentuknya, yakni individu laki-laki dan perempuan dalam institusi keluarga tersebut.

Namun, tidak dapat dipungkiri, bahwa sebuah institusi memerlukan managementnya demi terciptanya visi dan misi yang akan dicapai, seperti halnya institusi keluarga, maka di dalamnya juga diperlukan sistem managementnya. Sistem management suatu institusi tersebut tidak terlepas dengan sosok pemimpin atau yang biasa di kenal dengan kepala. Seiring dengan itu, institusi keluarga juga memerlukan sosok pemimpin atau kepala keluarga, sebagaimana yang termaktub dalam Q.S al-Nisāa (4); 34. Namun demikian, seiring perkembangan zaman, nilai-nilai yang 
termaktub dalam ayat tersebut juga mengalami banyak penafsiran pemahaman. Oleh karena itu, dalam tulisan ini akan mencoba menelaah konsep kepala keluarga antara laki-laki dan perempuan menurut Q.S al-Nisă $\overline{-}^{\text {ee }}$ (4); 34 dengan menggunakan pendekatan filsafat hukum Islam.

\section{Semiotika Charles Sanders Peirce}

Charles S. Peirce dalam Hawkes, mengungkapkan bahwa batasan semiotika adalah sebagai berikut: "Logic, in its general sense, is a believe I have shawn, only another name of semiotics, the quasi necessary, or formal doctrine of sign". (Dalam pengertian yang umum, logika - sebagaimana yang saya percaya dan saya tunjukan merupakan nama lain dari semiotika, yaitu doktrin tanda yang "pura-pura penting" atau doktrin tanda yang formal). Lebih dari itu, Peirce juga menjelaskan bahwa yang dimaksud doktrin tanda adalah tanda yang lahir dari pengamatan kita terhadap sifat-sifat tanda yang betul-betul kita ketahui. ${ }^{1}$ Berbeda dengan apa yang diungkapkan Saussure yang meyakini bahwa tanda memiliki dua sisi keterkaitan. Konsep semiotika yang dianut Peirce adalah bahwa teori tanda dibentuk oleh hubungan tiga sisi. Tiga sisi hubungan tersebut adalah Representamen (oleh Peirce disebut juga "tanda") yang berhubungan dengan Objek (sesuatu yang dirujuk oleh tanda atau representamen), yang dengan hubungan tersebut membuahkan Interpretant (sesuatu yang diserap oleh benak kita, sebagai hasil penghadapan kita dengan tanda itu sendiri).

Teori semiotik Peirce, dituntut untuk mengetahui perbedaan pengujian teori dalam terapan; antara teori sebagai hasil analisa dari hubungannya dengan fakta-fakta, dengan teori sebagai hasil pengujian dari metode (metodologi). Pengujian teori yang pertama bertujuan untuk verifikasi atau falsifikasi terhadap teori tersebut, karena teori yang pertama berisi preposisi -preposisi yang menjelaskan realitas fakta sehingga pengujiannya diukur dengan teori kebenaran korespondensi. Jika terdapat kesesuaian antara preposisi teori dengan realitas fakta maka teori tersebut terbukti (terverifikasi), tetapi sebaliknya jika tidak ada kesesuaian maka teori tersebut adalah salah (falsifikasi). Sedangkan pengujian teori yang kedua, yaitu metodologi, tidak dapat membuat verifikasi atau falsifikasi, karena jenis teori ini berisi proses-proses dalam penelitian dan

${ }^{1}$ Wildan Taufiq, Semiotika: Untuk Kajian Sastra dan al-Qur'an, (Bandung: Penerbit Yrama Widya, 2016), h. 9 
asumsi- asumsi yang dibangun dari proses tersebut, sehingga dari aplikasi yang akan dihasilkan proses-proses tersebut adalah kelebihan dan kekurangan, atau kekuatan dan kelemahan teori tersebut. Sedangkan asumsi-asumsi yang dikembangkan dalam teori tersebut yang dapat diuji adalah ketersambungannya. ${ }^{2}$

Definisi tanda dari Peirce berkaitan dengan kategori firstness, secondness, dan thirdness. Dengan demikian, Peirce membedakan tiga tipe tanda dasar kategori fenomenologinya. Tanda sebagai firstness yaitu tanda sebagai tanda itu sendiri, yang disebut representament. Tanda sebagai secondness yaitu objeknya, dan tanda sebagai thirdness, yaitu tanda sebagai interpretant (hasil interpretasi). Tiap hubungan ini tidak menunjukan bentuk keberadaan yang berbeda ataupun mewakili kelas fenomena yang berbeda.

Wildan Taufiq, dalam bukunya Semiotika: Untuk Kajian Sastra dan alQur'an, memberikan sebuah contoh penggunaan teori semiotik Peirce dengan mengambil contoh penggunaan Jilbab untuk umat Islam. Menurutnya menutup aurat adalah kewajiban setiap wanita muslim. Jilbab atau kerudung merupakan salah satu cara yang digunakan wanita muslim untuk menutupi auratnya dari bagian kepala sampai dada. Hal ini merupakan bagian tanda ketakwaan pemakainya terhadap perintah Allah. Sebagaimana yang termaktub dalam alQureean surat Al-Ahzāb/59 dan Al-Nūr/24: 33.

\section{Hakikat Pemimpin (Kepala Keluarga)}

Pemahaman terhadap definisi tentang sesuatu objek adalah awal yang sangat penting di dalam kerangka mempelajari, memahami, menganalisa serta menarik kesimpulan sesuatu objek. Sebab dengan rumusan melalui definisi yang jelas mengenai sesuatu akan mempermudah seseorang atau sekelompok orang untuk mempelajari dan mamahami lebih lanjut. Oleh karena itu, sebelum seseorang lebih jauh mendalami aspek-aspek yang berkaitan dengan permasalahan pokoknya, akan lebih tepat apabila langkah pertama, perlu dirumuskan lebih dahulu batasan atau definisi serta lingkup bahasan yang bersangkutan, ${ }^{3}$ yang dalam hal ini adalah pemimpin (kepala keluarga) berdasarkan hukum Islam. Namun, sebelumnya perlu di paparkan definisi pemimpin secara menyeluruh (tidak terbatas dalam konsep Islam saja) untuk menemukan

${ }^{2}$ Lexi Zulkarnain Hikmah, "Hadis Tentang Keutamaan Ibu: Suatu Tinjauan dan Analisis Semiotik Charles

3 Wahjosumidjo, Kepemimpinan dan Motivasi, (Jakarta: Ghalia Indonesia, 1985), h. 20-21. 
hubungan nilai-nilai yang terkandung dalam keilmuan Islam dan "umum".

Henry Pratt Fairchild sebagaimana yang dikutip oleh Kartini kartono, mendefinisikan pemimpin dalam pengertian luas ialah seseorang yang memimpin, dengan jalan memprakarsai tingkah laku sosial dengan mengatur, mengarahkan, mengorganisir atau mengontrol usahaupaya orang lain, atau melalui prestise kekuasaan atau posisi. Dalam pengertian yang terbatas,pemimpin ialah seseorang yang membimbing memimpin dengan bantuan kualitas-kualitas persuasifnya. ${ }^{4}$

Di dalam Islam telah digariskan bahwa setiap diri adalah pemimpin (minimal untuk dirinya sendiri) dan untuk kepemimpinannya itu ia dituntut untuk bertanggung jawab, tidak hanya kepada manusia tapi juga kepada Allah swt. ${ }^{5}$ Sebagaimana yang termaktub dalam QS Al-An"am(6); 165

Artinya : "Dan dia lah yang menjadikan kamu penguasa-penguasa di bumi dan dia meninggikan sebahagian kamu atas sebahagian (yang lain) beberapa derajat, untuk mengujimu tentang apa yang diberikan-Nya kepadamu. Sesungguhnya Tuhanmu amat cepat siksaan-Nya dan Sesungguhnya dia Maha Pengampun lagi Maha Penyayang”.

Di samping itu, terdapat pula hadis yang menyatakan kepemimpinan setiap individu bagi dirinya sendiri, yakni : Demikian pula Dengan institusi keluarga, didalamnya yang beranggotakan suami, isteri dan anak, juga membutuhkan pemimpin. samping itu, setiap entitas tersebut juga mempunyai tanggungjawab sebagai pemimpin diri sendiri, baik yang mempunyai posisi sebagai produsen (suami), distributor (isteri), dan konsumen (anak). Namun, dalam institusi keluarga tersebut, posisi laki-laki atau suami yang merupakan produsen, dalam umumnya masyarakat Indonesia merupakan pemimpin atau kepala keluarga.

Kepala keluarga, di samping mempunyai peranan sebagai produsen, dia juga mempunyai peranan yang lain, yakni seperti membimbing, mendidik, dan juga mengarahakan. Dengan demikian, dapat disimpulkan, bahwa hakikat kepala keluarga harus mempunyai beberapa fungsi dan tanggungjawab dalam kepemimpinannya, sebagaimana berikut:

1. Memberikan nafkah kepada keluarga (isteri dan anak-anaknya)

\footnotetext{
${ }^{4}$ Kartini Kartono, Pemimpin dan Kepemimpinan; Apakah Pemimpin Abnormal Itu?, (Jakarta: PT. RajaGrafindo Persada, 1998), h. 33

5 Ainur Rohim Fakih dan Iip Wijayanto, Kepemimpinan Islam, (Yogyakarta: UII Press, 2005), h. 15 .
} 
"Para ibu hendaklah menyusukan anak-anaknya selama dua tahun penuh, Yaitu bagi yang ingin menyempurnakan penyusuan. dan kewajiban ayah memberi Makan dan pakaian kepada Para ibu dengan cara ma'ruf. seseorang tidak dibebani melainkan menurut kadar kesanggupannya. janganlah seorang ibu menderita kesengsaraan karena anaknya dan seorang ayah karena anaknya, dan warispun berkewajiban demikian. apabila keduanya ingin menyapih (sebelum dua tahun) dengan kerelaan keduanya dan permusyawaratan, Maka tidak ada dosa atas keduanya. dan jika kamu ingin anakmu disusukan oleh orang lain, Maka tidak ada dosa bagimu apabila kamu memberikan pembayaran menurut yang patut. bertakwalah kamu kepada Allah dan ketahuilah bahwa Allah Maha melihat apa yang kamu kerjakan".

\section{Menegakkan Amar ma"eruf Nahi Munkar}

"Dan hendaklah ada di antara kamu segolongan umat yang menyeru kepada kebajikan, menyuruh kepada yang ma'ruf dan mencegah dari yang munkar; merekalah orang-orang yang beruntung".

3. Menjaga Keamanan Umat (Minimal Keamanan Keluarga).

"Dan siapkanlah untuk menghadapi mereka kekuatan apa saja yang kamu sanggupi dan dari kuda-kuda yang ditambat untuk berperang (yang dengan persiapan itu) kamu menggentarkan musuh Allah dan musuhmu dan orang orang selain mereka yang kamu tidak mengetahuinya; sedang Allah mengetahuinya. apa saja yang kamu nafkahkan pada jalan Allah niscaya akan dibalasi dengan cukup kepadamu dan kamu tidak akan dianiaya (dirugikan)".

\section{Pemimpin (Kepala Keluarga) Menurut QS. Al-Nisa' (4): 34.}

Dalam kitab-kitab klasik yang menjelaskan dan menafsirkan teks-teks ajaran Islam tidak asing lagi bahwa kaum laki-laki di gambarkan lebih superior dari kaum perempuan. Biasanya argument penguatan supremasi tersebut menggunakan ayat Al-

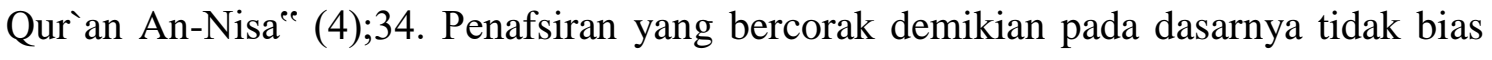
dipisahkan dengan situasi sosio kultural pada waktu penafsiran itu dilakukan. ${ }^{6}$

Di samping itu, hubungan penafsiran tersebut tidak terlepas dengan pandangan-

${ }^{6}$ Faiqoh, "Kepemimpinan Perempuan dalam Teks Konservatuf Agama”, dalamM. Jadul Maulana (ed.), Otonomi Perempuan Menabrak Ortodoksi, (Yogyakarta: LKPSM dan INPI PACT, 1999), h. 83. 
pandangan hadis yang bersifat misoginis (pandangan yang membenci perempuan). Sehingga melahirkan mufassir-mufassir yang cenderung untuk melebihkan laki-laki, seperti Abu Abdullah Muhammad binAhmad al-Anshari al-Qurthubi dalam tafsir al Qurthubinya (al-jami' li ahkam al- Qur'an) mengatakan;” dikatakan bahwa laki-laki memiliki kelebihan dalam akal dan pengaturan. Karena itu mereka memiliki hak memimpin perempuan. Sejalan dengan pemikiran al-Qurthubi, Abu Bakar Muhammad bin Abdullah atau yang dikenal dengan Ibnu al-Arabi (468-543 H) dalam Tafsir Ahkam al-Qur`an juga menyatakan-kesempurnaan akal dan kecerdasan laki-laki, kesempurnaan agamanya, ketaannya dalam jihad, dan amar makruf nahi munkar, serta laki-laki menyerahkan hartanya untuk perempuan, baik mas kawin ataupun nafkahkepemimpinan laki-laki atas perempuan berdasarkan An-Nisae (4): 34. Sedangkan Ibnu Katsir dalam Tafsir Ibnu Katsirnya, berpendapat bahwa kepemimpinan laki-laki dari perempuan tersebut adalah dengan sendirinya (fi nafsihi).

Dengan demikian, penafsiran terhadap QS An-Nisa ${ }^{e e}$ (4): 34 dengan mengambil beberapa rujukan pandangan ulama terdahulu dapat disimpulkan bahwa laki-laki merupakan kepala keluarga “pemimpin” dalam suatu tatanan keluarga.

\section{Penutup}

Al-Qur`an adalah hujjah bagi umat manusia, dan hukumnya merupakan undangundang yang wajib dipatuhi. Sebuah institusi memerlukan managementnya demi terciptanya visi dan misi yang akan dicapai, seperti halnya institusi keluarga, maka di dalamnya juga diperlukan sistem managementnya. Sistem management suatu institusi tersebut tidak terlepas dengan sosok pemimpin atau yang biasa di kenal dengan kepala.

Dalam kitab-kitab klasik yang menjelaskan dan menafsirkan teks-teks ajaran Islam tidak asing lagi bahwa kaum laki-laki di gambarkan lebih superior dari kaum perempuan. Biasanya argument penguatan supremasi tersebut menggunakan ayat AlQur`an An-Nisa"e (4);34. Penafsiran terhadap QS An-Nisa ${ }^{\text {ee }}$ (4): 34 dengan mengambil beberapa rujukan pandangan ulama terdahulu dapat disimpulkan bahwa laki-laki merupakan kepala keluarga "pemimpin” dalam suatu tatanan keluarga.

\section{Daftar Pustaka}

Kartini Kartono, Pemimpin dan Kepemimpinan; Apakah Pemimpin Abnormal Itu?, 
(Jakarta: PT. RajaGrafindo Persada, 1998),

Ainur Rohim Fakih dan Iip Wijayanto, Kepemimpinan Islam, (Yogyakarta: UII Press, 2005

Ibn Faris bin Zakariya ${ }^{e e}$, Abu al-Husain Ahmad. Mu jam alMakayis fi Al-Lughah. Cet.I; Bairut: Dar al-Fikr,1994.

Faiqoh, "Kepemimpinan Perempuan dalam Teks Konservatuf Agama", dalamM. Jadul Maulana (ed.), Otonomi Perempuan Menabrak Ortodoksi, (Yogyakarta: LKPSM dan INPI PACT, 1999)

Dr. Fuad Muhammad Fachruddin, Aurat dan Jilbab, (Jakarta: Pedoman Ilmu Jaya, 1984)

Lexi Zulkarnain Hikmah, "Hadis Tentang Keutamaan Ibu: Suatu Tinjauan dan Analisis

Semiotik Charles S. Peirce," (Skripsi S1 Fakultas Ushuluddin dan Filsafat, Universitas Islam Negeri Jakarta, 2008)

Wildan Taufiq, Semiotika: Untuk Kajian Sastra dan al-Qur'an, (Bandung: Penerbit Yrama Widya, 2016) 